\title{
SISTEM INFORMASI PENJUALAN PADA TOKO R2 COLLECTION DI RANTAUPRAPAT BERBASIS WEB
}

\author{
Rosnah Ritonga ${ }^{1)}$ \\ Mahasiswa Fakultas Sains dan Teknologi, Universitas Labuhanbatu \\ Email: rosnahritonga@gmail.com \\ Muhammad Halmi Dar ${ }^{2)}$ Iwan Purnama ${ }^{3)}$ \\ Dosen Fakultas Sains dan Teknologi, Universitas Labuhanbatu \\ Email:mhd.halmidar@gmail.com, iwanpurnama2014@gmail.com
}

\begin{abstract}
ABSTRAK
R2 Collection merupakan sebuah perusahaan yang bergerak di bidang penjualan pakaian wanita dan laki-laki, sistem penjualan pada Toko R2 yaitu setiap pembeli harus mendatangin langsung toko tersebut, selain itu dalam proses pembuatan laporan dan pencatatan barang belum terorganisir dengan baik sehingga mengakibatkan penumpukan barang dan hilang nya data transaksi-transaksi penjualan, maka diperlukan suatu sistem modern yang sangat sesuai untuk mendukung kemajuan dan perkembanan perusahaan, sehingga dapat mengatasi permasalahan atau kendala pada sistem yang sedang berjalan. Dalam hal ini guna memaksimalkan sistem yang ada digunakanlah rancangan menggunakan bahasa UML (Unified Modelling Language) dan diimplementasikan dengan menggunakan PHP, Xampp,Web Server dan MySQL. Dengan memanfaatkan sistem yang sedang diusulkan ini secara tepat, pengawasan atau kontrol terhadap pemrosesan penjualan menjadi lebih baik dan mudah dalam melakukan penjualan barang maupun pencatatan penerimaan barang.
\end{abstract}

Kata Kunci : Sistem, Informasi, e-commerce, Bahasa UML, PHP, MySQL.

\section{I.PENDAHULUAN}

Salah satu teknologi yang akan memberikan kemudahan dalam penjualan yaitu dengan komputer dan aplikasi-aplikasi nya[1]. Terkadang sebuah toko hanya memikir kan peningkatan pendapatan nya saja tidak memikir kan bagaimana penggolahan data dengan baik. Oleh karena itu sangat penting sekali meningkatkan sistem nya dari yang konvensional menjadi terkomputerisasi. Dengan adanya terkomputerisasi tersebut diharapkan dapat menghasilkan data yang cepat dan informasi akurat sehingga dapat digunakan oleh pemilik.
Sistem penjualan yang berlangsung pada toko R2 Collection saat ini yaitu setiap pembeli harus mendatangi toko secara langsung untuk melakukan kegiatan transaksi pembelian. hal ini berakibat terhadap ketidakefisienan jumlah biaya yang relatif tidak sedikit dan juga tempat yang terbatas, selain itu dalam proses pembuatan laporan dan penyimpanan data belum terorganisir dengan baik sehingga mengakibatkan terjadinya penumpukan atau hilangnya data-data transaksi penjualan.

Sekarang ini internet tidak hanya digunakanuntuk memperoleh informasi saja, melainkan dapat digunakan 
sebagai media untuk melakukan bisnis dengan membangun sebuah website[2]. Sistem yang akan dirancang yaitu sistem informasi penjualan yang menggunakan database $M y S Q L$ dan menggunakan bahasa pemograman PHP. Laporan-laporan yang dulu nya masih menggunakan buku besar yang ditulis secara manual, akan digantikan dengan sistem laporan yang sudah terkomputerisasi.

Mengingat pentingnya hal diatas, sistem informasi sangat diperlukan dalam suatu perusahaan maka penulis melakukan penelitian dan menuangkan dalam bentuk skripsi dengan judul "Sistem Informasi Penjualan Pada Toko R2 Collection di RantauPrapat Berbasis Web".

\section{LANDASAN TEORI}

\subsection{Sistem Informasi}

Sistem informasi merupakan sistem di dalam suatu organisasi yang merupakan kombinasi dari orang-orang, fasilitas, teknologi, media prosedur-prosedur dan pengendalian yang ditujukan untuk mendapatkan jalur komunikasi penting, memproses tipe transaksi rutin tertentu, memberi sinyal kepada manajemen dan yang lainnya terhadap kejadian-kejadian internal dan eksternal yang penting dan menyediakan suatu dasar informasi untuk pengambilan keputusan[3].

\subsection{Penjualan}

Penjualan merupakan suatu kegiatan yang dilakukan sebagian manusia dalam menjual barang dagangan yang dimiliki baik itu barang ataupun jasa kepada pasar agar mencapai suatu tujuan yang diinginkan[4]. Maka dari itu sistem informasi penjualan merupakan sistem yang melibatkan barang atau jasa dalam suatu organisasi, prosedur, data serta sarana pendukung untuk mengoperasikan sistem penjualan, sehingga menghasilkan informasi yang bermanfaat bagi pihak manajemen dalam menggambil keputusan.

\subsection{Website}

Website merupakan kumpulan halaman-halaman yang berbentuk teks, gambar, suara dan lainnya yang tersimpan dalam sebuah internet webserver, halaman tersebut berisi bahasa pemrograman yang saling berhubungan yang dihubungkan melalui hyperlink atau URL (Uniform Reseource Locator) [5].

\subsection{Basis Data}

Basis data merupakan salah satu komponen yang mendukung nya sebuah aplikasi, karna basis data merupakan tempat penyimpanan data-data yang digunakan untuk aplikasi tersebut

\section{MySQL}

MySQL merupakan sistem manajemen database SQL yang bersifat Open Source dan paling populer saat ini. Sistem Database MySQL mendukung beberapa fitur seperti multithreaded, multi-user, dan SQL database management system (DBMS).Database ini dibuat untuk keperluan sistem database yang cepat, handal, dan mudah digunakan[5]. Mysql berfungsi sebagai komponen basis data dalam 
LAMP. Popularitas sebagai aplikasi web dikarenakan kedekatannya dengan popularitas PHP, sehingga seringkali disebut sebagai Dynamic Duo[6].

\section{XАMPP}

Xampp merupakan sebuah paket kumpulan software yang terdiri dari Apache, MySQL, phpMyAdmin, PHP, Perl, Filezilla dan lain-lain yang berfungsi untuk memudahkan instalasi lingkungan PHP, dimana biasanya lingkungan pengembangan web memerlukan PHP, Apache, $M y S Q L$, dan phpMyAdmin serta software lainnya yang terkait dengan pengembangan web[5].

\subsection{Bahasa Pemograman}

Bahasa Pemrograman yaitu memerintah komputer untuk mengolah data sesuai dengan alur berpikir yang kita inginkan. ada beberapa bahasa pemograman yaitu :

\section{PHP}

PHP adalah bahasa program yang digunakan untuk membuat aplikasi berbasis web (website, blog, atau aplikasi web) dan bahasa pemrograman script yang paling banyak dipakai saat ini[5].. Contoh aplikasi lain yang lebih kompleks berupa CMS yang dibangun menggunakan PHP adalah Mambo, Joomla!, Postnuke, Xaraya, dan lain-lain.

\section{HTML}

HTML itu bahasa yang fleksibel karena tidak tergantung pada suatu platform (sistem operasi) tertentu. HTML terdiri dari tagtag yang mendefenisikan elemen tertentu pada sebuah halaman web. HTML merupakan bahasa yang tidak case sensitive, tidak seperti bahasa pemrograman server-side seperti PHP atau ASP.

\subsection{Waterfall}

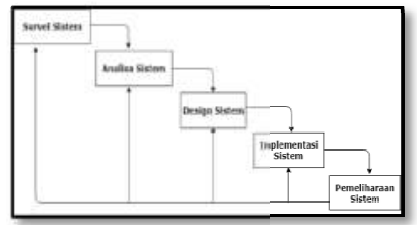

\section{Gambar 2.1 Gambar Waterfall}

Metode ini merupakan metode yang sering digunakan oleh penganalisa sistem pada umumnya. Inti dari metode waterfall adalah pengerjaan dari suatu sistem dilakukan secara berurutan atau secara linear [6]. Jadi setiap tahap harus diselesaikan terlebih dahulu secara penuh sebelum diteruskan ke tahap berikutnya untuk menghindari terjadinya pengulangan tahapan.

\subsection{UML}

UML adalah sebuah bahasa yang berdasarkan grafik / gambar untuk memvisualisasi, menspesifikasikan, membangun, dan pendokumentasian dari sebuah sistem pengembangan software berbasis OO (Object Oriented)[6].UML juga menjadi salah satu cara untuk mempermudah pengembangan aplikasi yang berkelanjutan. Aplikasi atau sistem yang tidak terdokumentasi biasanya dapat menghambat pengembangan karena developer harus melakukan penelusuran dan mempelajari kode program. UML terbagi beberapa bagian yaitu :Use Case Diagram, Activity Diagram, Sequeen Diagram, Class Diagram Dan Deployment Diagram

\subsection{Web Hosting}

Web Hosting adalah salah satu bentuk layanan jasa penyewaan tempat di Internet yang memungkinkan perorangan ataupun 
organisasi menampilkan layanan jasa atau produknya di web / situs Internet[9].Layanan hosting IndoWebsite dilengkapi dengan fitur dan teknologi terbaru yang memudahkan pengguna untuk mengelola website, serta technical support full 24 jam.

\section{III.METODOLOGI PENELITIAN}

\subsection{Metode Pengumpulan Data}

Metode pengumpulan data berupa suatu pernyataan tentang keadaandan kegiatan tertentu. Pengumpulan data dilakukan untuk mendapatkan suatu informasi yang dibutuhkan dalam mencapai tujuan penelitian. Penulis menggunakan beberapa metode atau teknik dalam mengumpulkan data. Metode pengumpulan data penelitian dapat ada 3 bagian yaitu Observasi, Wawancara dan Study Pustaka.

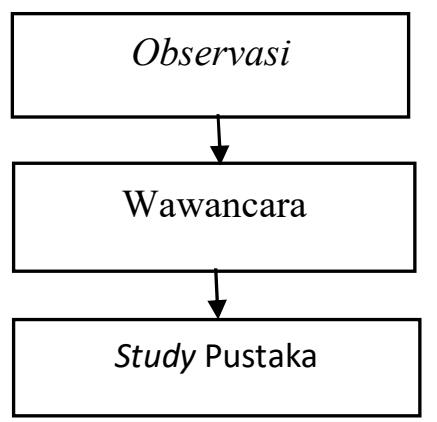

\section{Gambar 3.1 Metode Pengumpulan Data}

1. Observasi

Dilakukan dengan cara mengamati secara langsung objek penelitian pada toko R2 Collection Jln SM. Raja Rantauprapat untuk memberikan gambaran yang sesungguhnya dari objek yang diteliti.Pada saat mengamati secara langsung penulis mengetahui bagaimana proses transaksi dan penyimpanan produk di R2 Collection dari produk masuk, barang disimpan dan pelayanan toko.

\section{Wawancara}

Wawancara yang dilakukan oleh penulis langsung kepada pemilik toko untuk menggumpulkan data yang diperlukan oleh penulis. Penulis melakukan beberapa wawancara dilakukan dengan Bapak Rukimin (Pemilik Toko).

\section{Study Pustaka}

Pada tahap ini kegiatan yang dilakukan adalah mempelajari dan meneliti berbagai sumbar bacaan yang mempunyai hubungan dengan permasalahanpermasalahan yang dihadapi dan yang dapat digunakan sebagai dasar dalam penelitian ini, seperti buku-buku, jurnal, skripsi, catatan-catatan maupun referensi penelitian terdahulu. Daftar buku dan referensi dalam penyusunan tugas akhir ini dapat dilihat pada daftar pustaka.

\section{Implementasi Dan Pengujian Sistem}

Berikut ini adalah hasil rancangan sistem informasi penjualan pada toko R2 Collection.

\section{Halaman Utama Web}

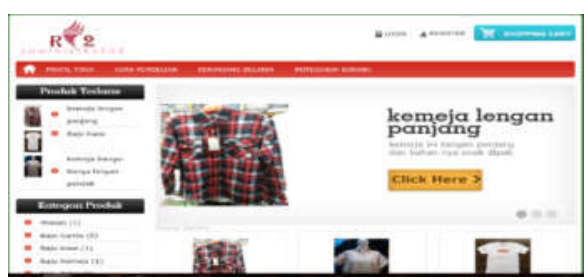

Gambar 4.1 Halaman Utama

Web 
Pada gambar 4.1 terdapat beberapa menu seperti : profil toko, cara pembelian, kontak dan pemesanan barang

\section{Halaman Login}

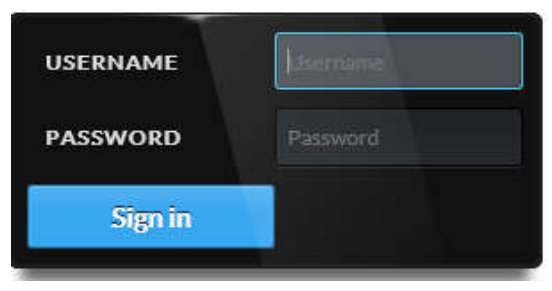

\section{Gambar 4.2 Halaman Login}

Pada gambar 4.2 merupakan form yang digunakan oleh admin untuk masuk ke sistem informasi penjualan $\mathrm{R} 2$, langkah-langkah pengisian form login antara lain adalah, admin harus mengisikan username dan password kemudian setelah terisi klik login, jika login gagal maka akan muncul pernyataan anda gagal login, jika berhasil maka akan halaman utama admin.

\section{Halaman Register}

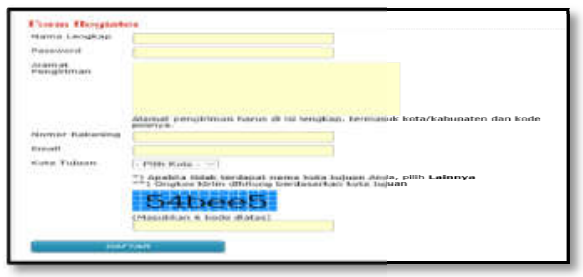

Gambar 4.3 Halaman Register

4. Halaman Transaksi Penjualan

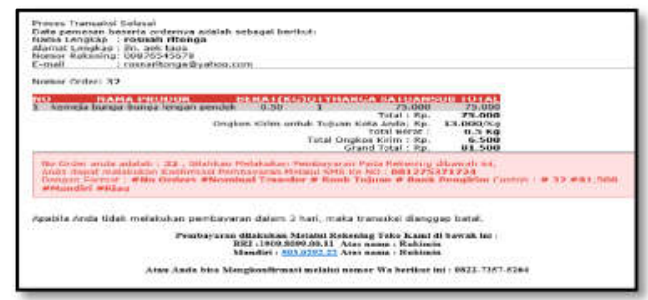

Gambar 4.4 Halaman Transaksi Penjualan

\section{Halaman Penginputan Data Produk}

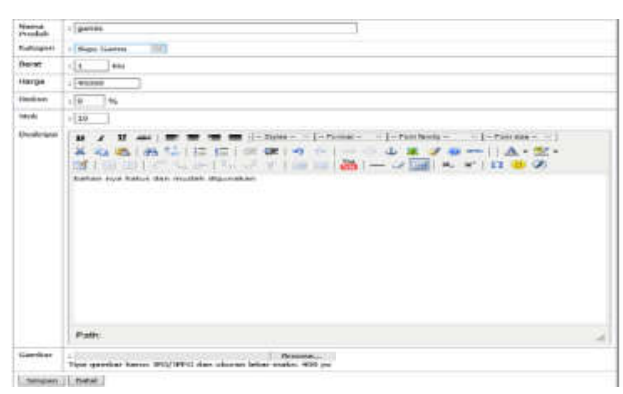

Gambar 4.5 Halaman

Penginputan Data Barang

1.Halaman Laporan Penjualan

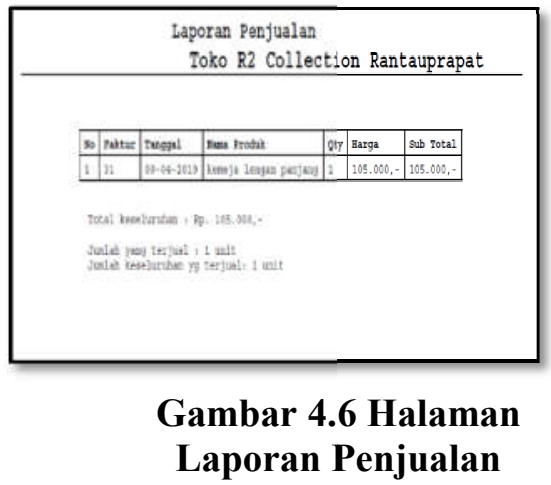

\section{IV.Kesimpulan}

Berdasarkan rancangan dan implementasi yang telah dilakukan dan diuraikan pada bab-bab sebelumnya, maka penulis dapat mengambil kesimpulan sebagai berikut :

1. Melalui sistem informasi ini, pemilik toko dapat melakukan pengecekan data transaksi penjulan, transaksi pembelian, stok, dan lain - lain secara mudah dan akurat dan dengan waktu yang singkat.

2. dengan sistem informasi penjualan ini dapat membantu kasir dalam proses pengelolahan data dan transaksi penjualan. 
3. Sistem informasi penjualan yang telah dibuat ini diharapkan dapat memberikan kemudahan kepada para pelanggan dalam melakukan pemesanan produk tanpa harus datang secara langsung ke tempat.

\section{DAFTAR PUSTAKA}

[1] J. O. Sembiring, U. Santo, T. Sumatera, J. Setiabudi, and N. F. Tanjungsari, "Sistem Informasi Penjualan Barang dan Jasa pada Studio Photo Topaz Hexagon Medan Berbasis Web," vol. 2, no. 2, pp. 153-160, 2017. [2] R. Hidayat, "Perancangan Sistem Informasi Penjualan Barang Handmade Berbasis Website Dengan Metode Waterfall," Simp. Nas. Ilmu Pengetah. dan Teknol., pp. 175-183, 2014.

[3] Christian Putri, Ed., Analisis Sistem Informasi. Tata Sutabri, 2012.

[4] A. Prasetyo and S. Rahel, "Sistem Informasi Penjualan Berbasis Web Pada PT. Cahaya Sejahtera Sentosa Blitar," Sist. Inf. Penjualan Berbas. Web Pada PT. Cahaya Sejah. Sentosa Blitar, vol. 10, no. 2, pp. 1-16, 2016.

[5] Membangun website tanpa modal menggunakan CMS Wordpress beserta domain dan hosting gratis. Andi, 2010.

[6] I. Purnama et al., "Sistem Informasi Kursus IBAY Komputer Berbasis Web dan Mobile Android," vol. 05, no. 01, pp. 23-31, 2019.

[7] S. Haryanti and T. Irianto, "Rancang Bangun Sistem Informasi E-Commerce Untuk Usaha Fashion Studi Kasus Omah Mode Kudus," Jornadas GESCO, 13., 2003, Montevideo, Uruguay., vol. 3, no. 1, pp. 8-14, 2003.

[8] A. Hendini, "PEMODELAN UML SISTEM INFORMASI MONITORING PENJUALAN DAN STOK BARANG (STUDI KASUS: DISTRO ZHEZHA PONTIANAK)," $J$. KHATULISTIWA Inform., vol. IV, no. 2, pp. 107-116, 2016.

[9] I. Purnama, "APLIKASI PEMESANAN KULINER HALAL RANTAUPRAPAT BERBASIS," vol. 6, no. 3, pp. 7-13, 2018. 